Uma prova disso é a "descoberta" das debêntures, que é uma fonte de financiamento a longo prazo. $O$ gráfico 1 indica a sua popularidade nos últimos 18 meses, indo de abril de 1980 a agosto de 1981.

\section{Tendéncia na estrutura financeira das empresas}

João Carlos Hopp

Professor na EAESP/FGV, no Departamento de Finanças.

Nesta conjuntura de crise, uma posição que certamente não é tranqüila é a do vice-presidente de finanças. Senão vejamos:

a) $\mathbf{O}$ saldo de duplicatas a receber atinge valores alarmantes, ño porque haja um grande aumento no volume de vendas, mas em razão da dilatação do prazo médio de cobrança.

b) $\mathrm{O}$ saldo de estoques, principalmente o de produtos acabados, é cada vez maior em virtude da retração das vendas.

c) O "policiamento" do fornecedor da matéria-prima sobre as duplicatas a pagar é muito mais rigoroso. $O$ tradicional "vamos esperar 10 dias" foi substituído por "manda executar caso não seja pago em 48 horas".

O resultado desta situação é que o administrador financeiro encontra-se em uma situação contraditória.

O seu capital circulante líquido (capital de giro) é altamente positivo, pois os seus principais ativos circulantes (duplicatas a receber e estoques) estão aumentando consideravelmente e o passivo circulante mais importante (fornecedores) tende a diminuir, porém não há condiçres de solver seus compromissos.

Acrescente-se ao quadro acima a política governamental de "arroxo" creditício com o objetivo de conter a inflação. $O$ aturdido executivo financeiro vai ao Banco e não consegue o desconto das duplicatas! $\mathrm{E}$ quando consegue, as taxas são de tal monta que a empresa "passa a trabalhar para o Banco" conforme afirmam os empresários.

Isto tem levado a uma mudança na estrutura financeira (lado direito do Balanço) das empresas brasileiras. $O$ executivo financeiro brasileiro tradicionalmente não utiliza a fonte de passivo a longo prazo, porém ele está se apercebendo de que talvez a solução esteja na reformulação da política de endividamento para atravessar essa corrente de "maré baixa".

\section{Lançamentos de debêntures}

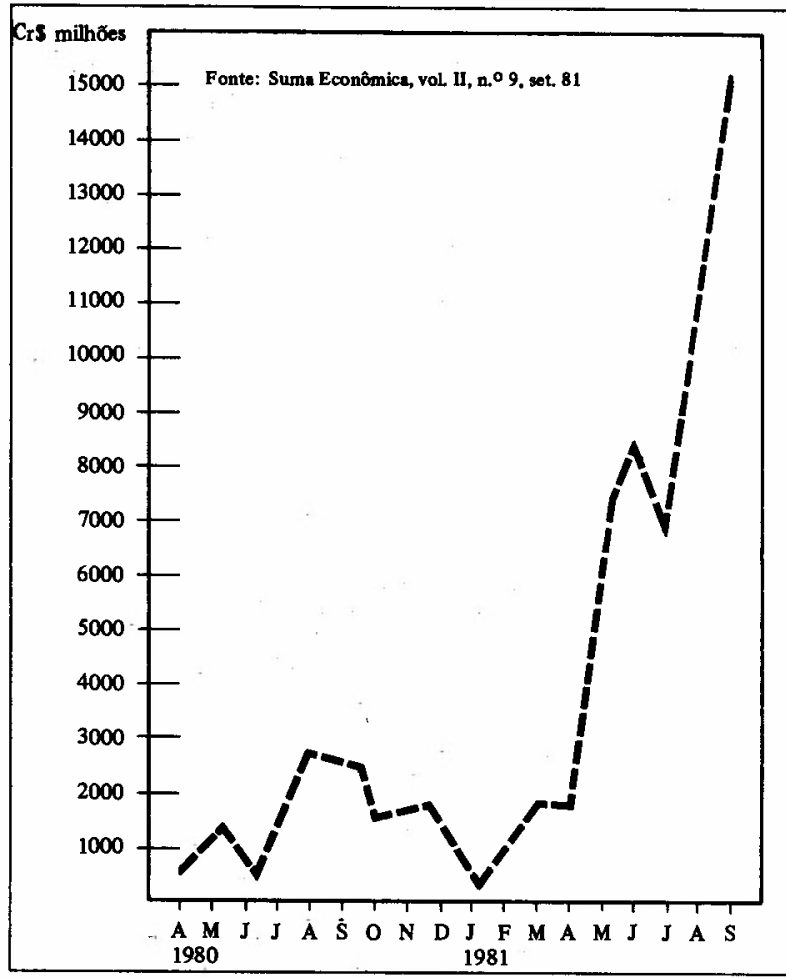

A Comissão de Valores Mobiliários registrou emis. sões de debêntures no valor de $\mathrm{Cr} \$ 43$ bilhðes até agosto de 1981 e estão sendo analisados pedidos de mais 30 bilhoes que devem procurar recursos no mercado.

Com esta diretriz, a estrutura financeira das empresas apresenta uma nova feição, que se ajusta com a teoria financeira. $O$ inevitável aumento do capital circulante permanente deve ser financiado com recursos de longo prazo, e não com o tradicional desconto de duplicatas. 